\title{
GEOSPATIAL APPROACH FOR GROUNDWATER EXPLORATION AT UTM JOHOR BAHRU CAMPUS
}

\author{
M.A. Zamari ${ }^{1}$, T.A. Musa ${ }^{1}$, E.T. Mohamad ${ }^{2}$, I.A.Musliman ${ }^{1}$, W.A.W. Aris ${ }^{1}$ \\ ${ }^{1}$ Geomatic Innovation Research Group (GnG), Faculty of Built Environment \& Surveying, Universiti Teknologi \\ Malaysia, 81310 Johor Bahru, Johor, Malaysia \\ acapzamari@gmail.com, tajulariffin@utm.my \\ ${ }^{2}$ Centre of Tropical Geoengineering (GEOTROPIK), School of Civil Engineering, Faculty of Engineering, Universiti Teknologi \\ Malaysia, 81310 Johor Bahru, Johor, Malaysia - edy@utm.my
}

KEY WORDS: GPS, Groundwater, UAV mapping, GIS

\begin{abstract}
:
A major concern in groundwater exploration is to determine a precise location of the groundwater resources. The geospatial technology such as UAV mapping, precise GPS surveying and GIS data management could be integrated with other geospatial information to augment the groundwater exploration. The aim of this research project is to support groundwater exploration at UTM, Johor Bahru campus by employing the geospatial approach. In doing so, the aerial photo captured by using UAV and GPS will be utilised to support geology and geophysics data collection. Subsequently, subsurface information such as lithology, stratigraphy and geological structures have been used to form the subsurface profile. Afterward, development of the groundwater geospatial database had commenced by using a GIS approach. It is expected that by integration of geospatial technology in groundwater exploration works will help to identify the location of potential groundwater zone in the study area.
\end{abstract}

\section{INTRODUCTION}

Malaysia is a tropical country and receives an annual rainfall of $2500 \mathrm{~mm}$ until $3000 \mathrm{~mm}$ (Paterson et al, 2015). In fact, the country has a considerable degree of surface water reserves due to river and lakes. However, there are some disturbing issues to meet the demand for water resources, especially water supply for drinking (Ahmad et al, 2014). This problem arises from several factors such as widespread water pollution and weather changing. In fact, this problem will cause incensement cost in the process of clean water treatment and the amount of fresh water supply also decreases (Abou-Elela et al, 2019). Hence, there is an alternative to overcome this problem with fully utilized of groundwater resources (Nescerecka et. al, 2018).

The best approach to identify subsurface layer thickness and location of groundwater resources are provided by using drilling test. However, this approach is too expensive and requires skilled manpower (Yang et al, 2018). Nowadays, the integration of geological and geophysical studies is commonly used in groundwater exploration. Usually this approach is combined with geoinformation knowhow such as field survey and supported with existing topographic and thematic maps. Nevertheless, the advancement in geospatial technology such as Unmanned Aerial Vehicle (UAV) mapping, precise Global Positioning System (GPS) surveying and Geographical Information System (GIS) data management could be utilized to augment the groundwater exploration (Savita et al, 2018; Pandey et. al, 2015; Mishra et al, 2019; Nair et al, 2019; Nag et al, 2019; Thakur et al, 2018). Moreover, the applications of geospatial technology such as GIS can reduce cost and time in order to assess and manage geospatial information of groundwater resources (Adiat et al, 2012).
Groundwater exploration in this country requires a support and integration of the geoinformation technology into the exploration works to maximise high chances in identifying groundwater resources potential zone. The aim of this research project is to support groundwater exploration at Universiti Teknologi Malaysia, Johor Bahru campus by employing the geospatial approach. In doing so, the geospatial technologies such as UAV mapping approach and GPS positioning has been employed to generate the topographic map and to support geology and geophysics data collection in the study area, respectively.

Subsequently, the existing subsurface information such as lithology, stratigraphy and geological structures have been utilised to form the subsurface profile in the study area. Subsequently, development of the geospatial database and analysis for groundwater exploration at UTM has been commenced by using a GIS approach. It is expected that the technology and analysis by using the geospatial approach will provide a promising result for groundwater exploration project at UTM. 


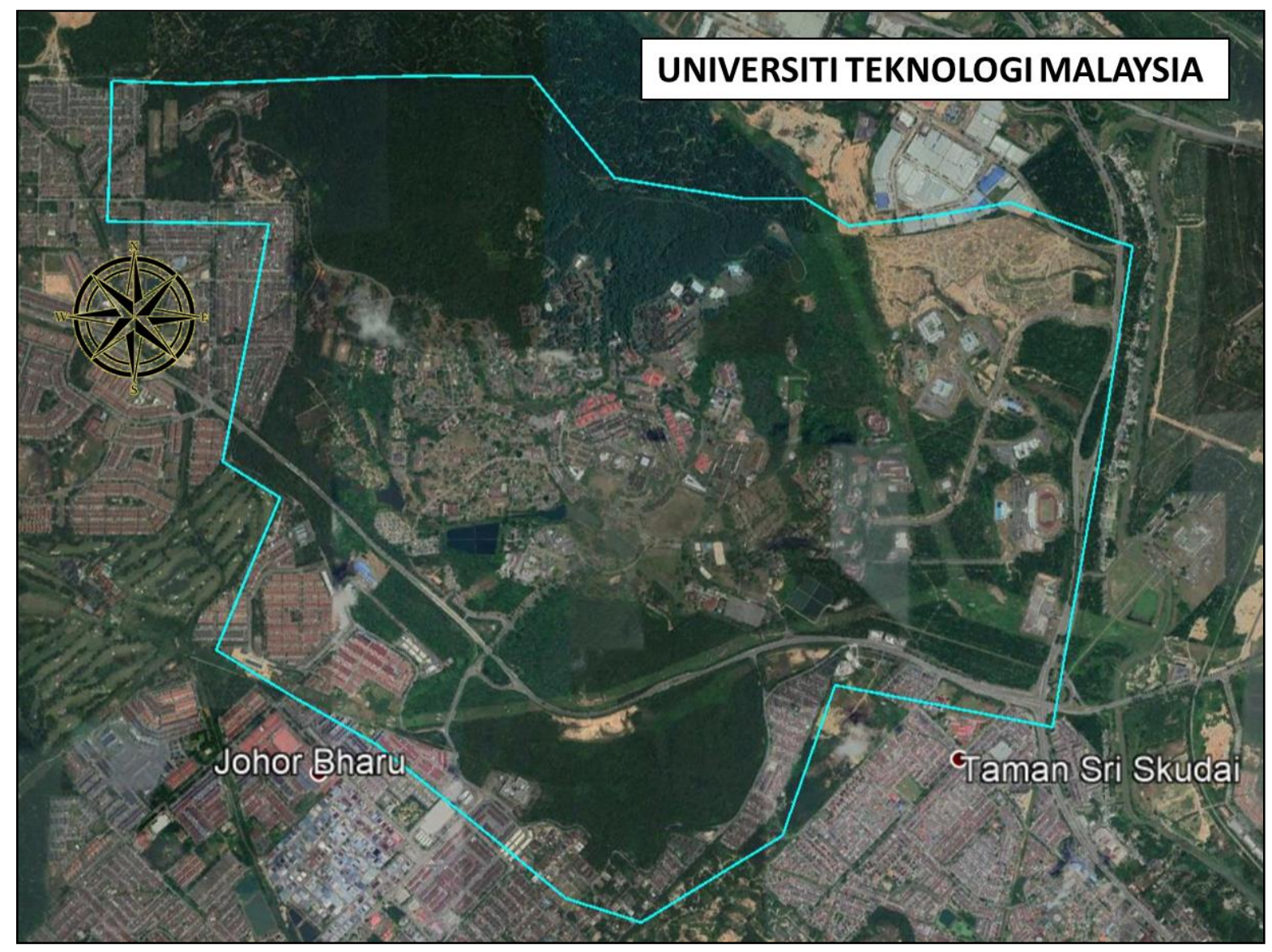

Figure.1 Location of the study area.

\section{METHODOLOGY}

The study area was conducted at Universiti Teknologi Malaysia (UTM), Johor Bahru Campus within the district of Johor Bahru in south of Johor (Figure 1). The project cover 2,816 acre of land area with range of latitude between $1^{\circ} 34^{\prime} 7^{\prime \prime} \mathrm{N}$ to $1^{\circ} 34^{\prime}$ $36^{\prime \prime} \mathrm{N}$ and longitude between $103^{\circ} 36^{\prime} 52^{\prime \prime} \mathrm{E}$ to $103^{\circ} 38^{\prime} 20^{\prime \prime} \mathrm{E}$.

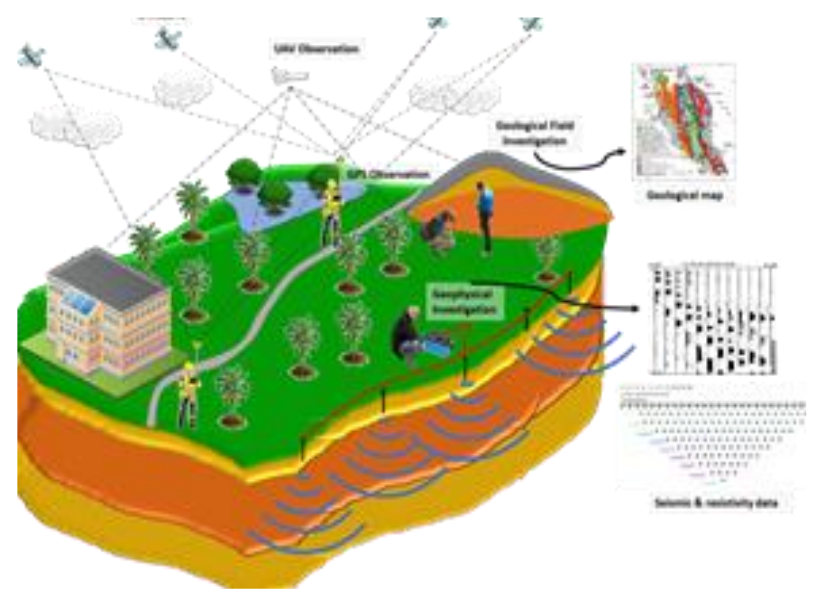

Figure 2 Conceptual design of the project.

The conceptual design of the project is illustrated in Figure 2. There are two types of data that have been utilized in this study which are primary and secondary data. The primary data consists of Global Positioning System (GPS) measurements and digital aerial image meanwhile the secondary data consist of geophysical and geological data based on the previous research in the study area.

\subsection{UAV Data Collection.}

In this study the digital aerial images were collected using multi rotor UAV. There are two important phases in this data collection which are the establishment of ground control point (GCP) and check point (CP) by using the GPS observation technique, and flight planning preparation for the study area.

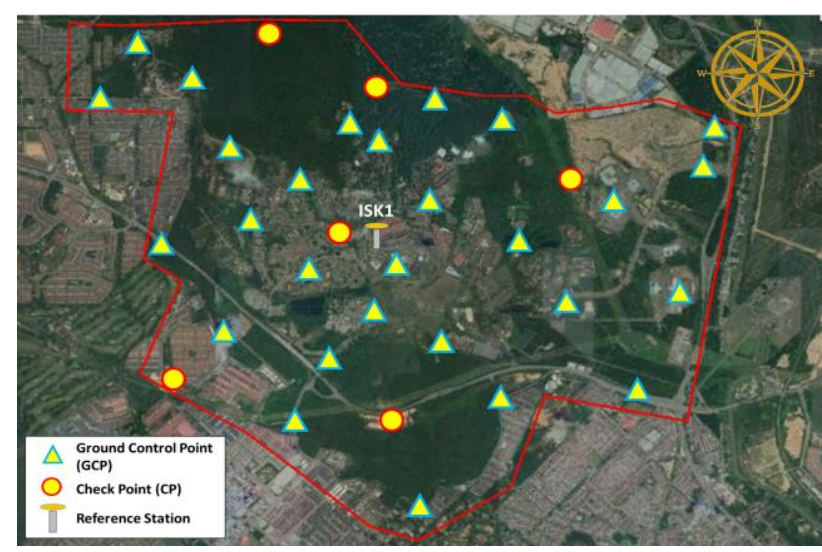

Figure 3 Location of GCP and CP in the study area.

The GCP and CP will be used as reference for UAV processing and to validate the accuracy of photogrammetric products, respectively. Figure 3 shows the location of GCP and CP within 
the study area. There were two methods of GPS observations have been applied in this study, i.e., static and fast static technique. The static observation was used to establish the GCP stations in the study area and these stations were relatively connected with reference stations of MyRTKnet and NRC-net that being operated by the Department of Surveying \& Mapping Malaysia (DSMM) and the Geomatic Innovation Research Group (GnG), respectively. Meanwhile, the fast-static observation was applied to establish few CP stations in the study area. The static observation was conducted for 1 hours for each control station while fast static observation was conducted from 30 to 45 minutes for each CP. The GPS data were processed by using Trimble Business Centre (TBC) software in post-processing mode. As the result, this process has provided final GCP and CP coordinates in Geocentric Datum of Malaysia 2000 (GDM2000) and these 3D coordinates were projected onto 2D mapping coordinates system.

There are several parameters were required in preparation of the flight planning such as overlapping of images, flight path determination and UAV altitude as shown in Table 1 . The DroneDeploy application software has been utilised in order to prepare the flight planning in this study. Figure 4 shows the design of flight planning for UAV data collection. In this study, the proposed flight altitude in this data collection was 100 meter with lapped of images was $75 \%$ for the whole study area.

\begin{tabular}{|c|c|c|}
\hline \multirow[t]{2}{*}{ Table 1} & \multicolumn{2}{|c|}{ Parameter for preparation of the flight plan. } \\
\hline & Parameter & Details \\
\hline & Flight Altitude & 100 Meter \\
\hline & Coverage & 2816 acre \\
\hline & Flight direction & 0 \\
\hline & Side lapping of image & $75 \%$ \\
\hline & End lapping of image & $75 \%$ \\
\hline
\end{tabular}

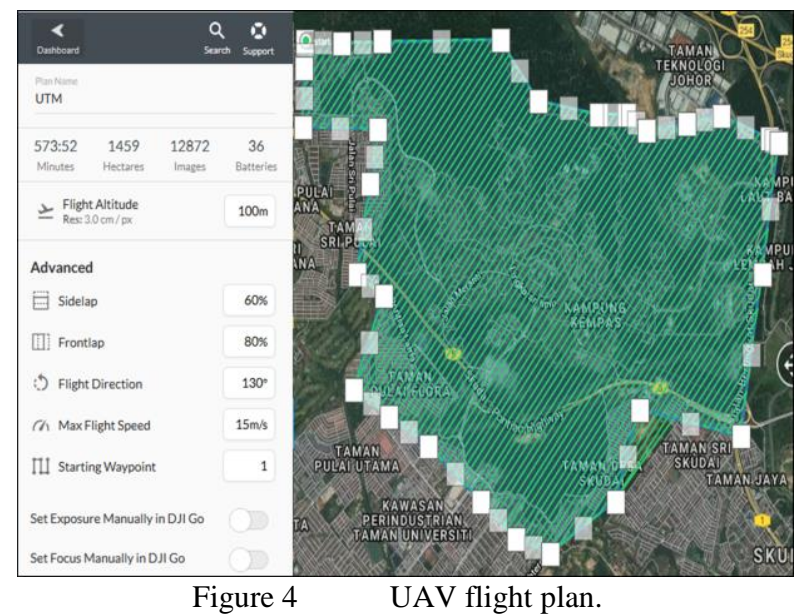

In this study, the digital aerial images of the study area as captured by the UAV technique have been processed in order to produce digital orthophoto and digital elevation model (DEM). The Agisoft software was used to process the digital aerial images and Figure 5 shows the processing procedure.

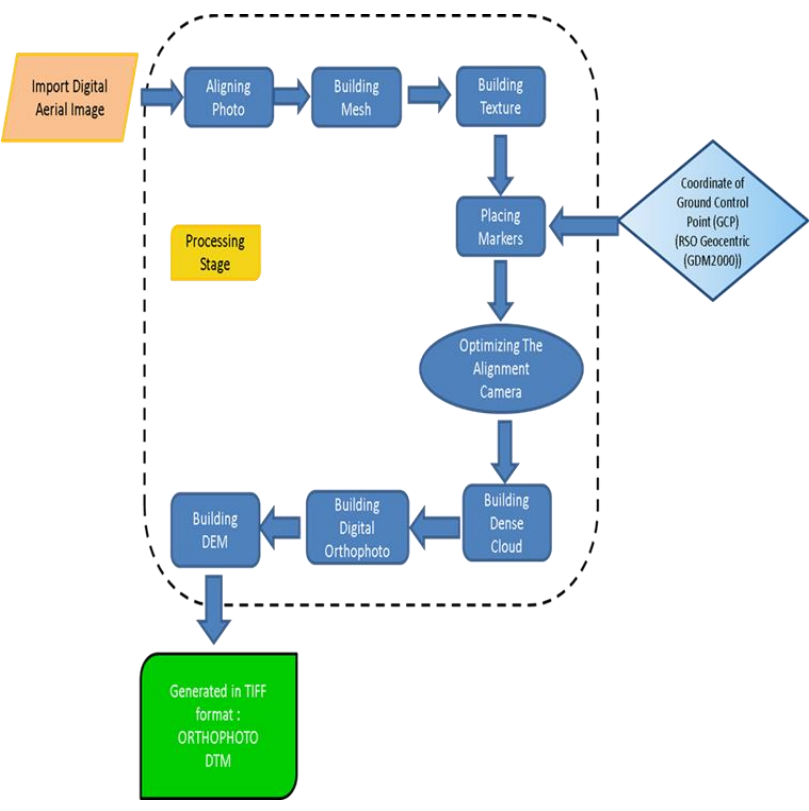

Figure 5 Procedure of UAV data processing.

\subsection{Geological and Geophysical Data.}

For geological data, the existing geological map in hardcopy has been digitized and georeferenced by using GIS and GPS technique respectively. In addition, geology field investigation has been conducted to verify geological information in the study area. During this field investigation, the GPS observation has been utilized to validate location of the geological information in the geological map (Figure 6).

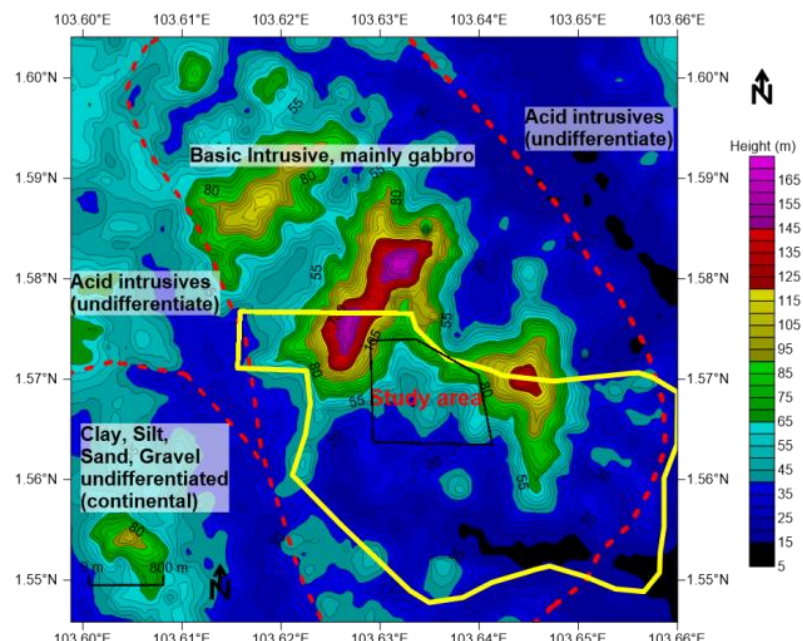

Figure 6 Site elevation and geology boundary of the study area.

Meanwhile, geophysical data that based on previous resistivity and seismic survey lines have been integrated into the geospatial database for further analysis. There were 4 lines of resistivity and 1 line of seismic have been established within the study area (Figure 7). Each length of resistivity line was 800 meters meanwhile length of seismic line was 200 meters. During this seismic survey, the GPS observation has been employed to provide precise location of the seismic line. 


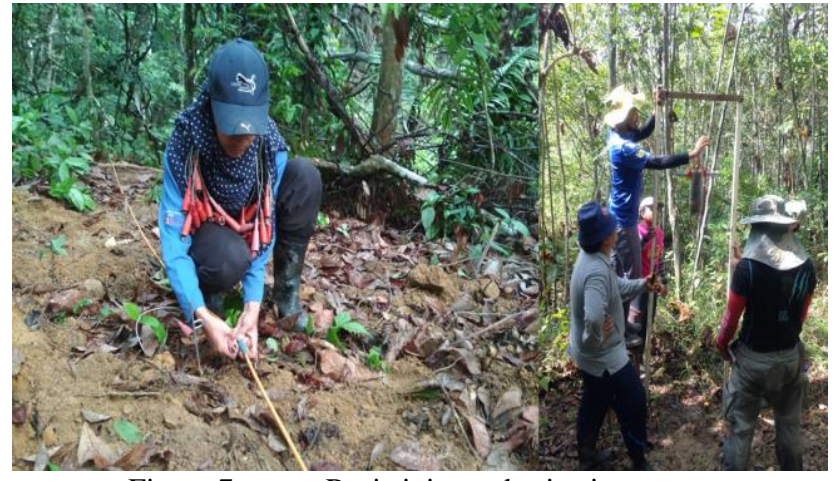

Figure 7

Resistivity and seismic survey

\section{RESULT AND DISCUSSION}

\subsection{Development of Geospatial Database and Mapping}

Geospatial database is a medium for storing and managing the spatial data and its attributes that can be applied in groundwater exploration work. Three (3) components will be used to develop a geospatial database of the study area: (1) feature datasets, (2) raster dataset and (3) tables. The overall framework in developing a geospatial database for this study is illustrated in Figure 8.
Based on this database, the information such as topography and profile information of the geological subsurface have been integrated in the GIS environment. Figure 9 shows topographic information of the study area and is being used as the base map for the geospatial database of groundwater exploration in UTM.

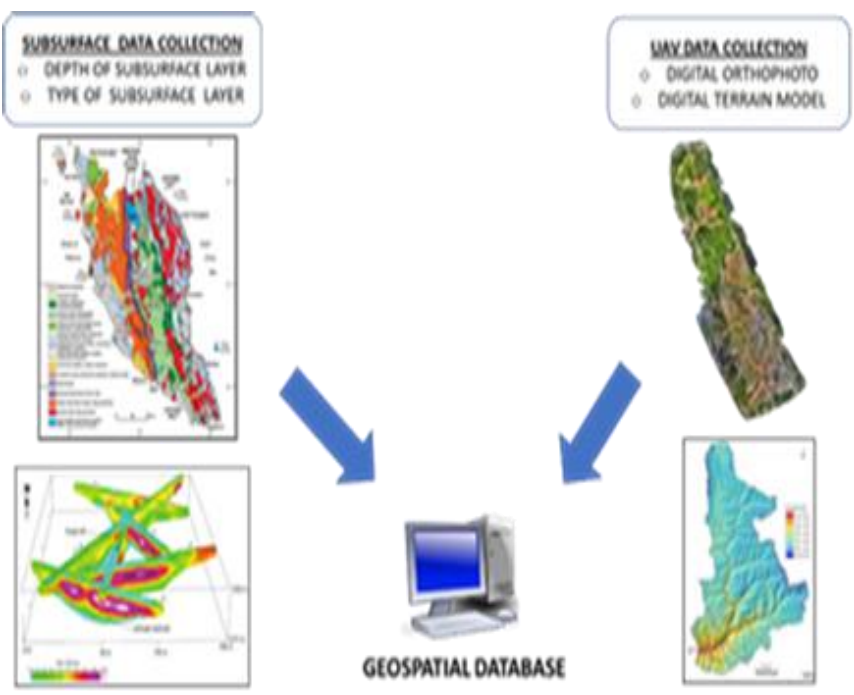

Figure 8 Framework in development of groundwater exploration database.

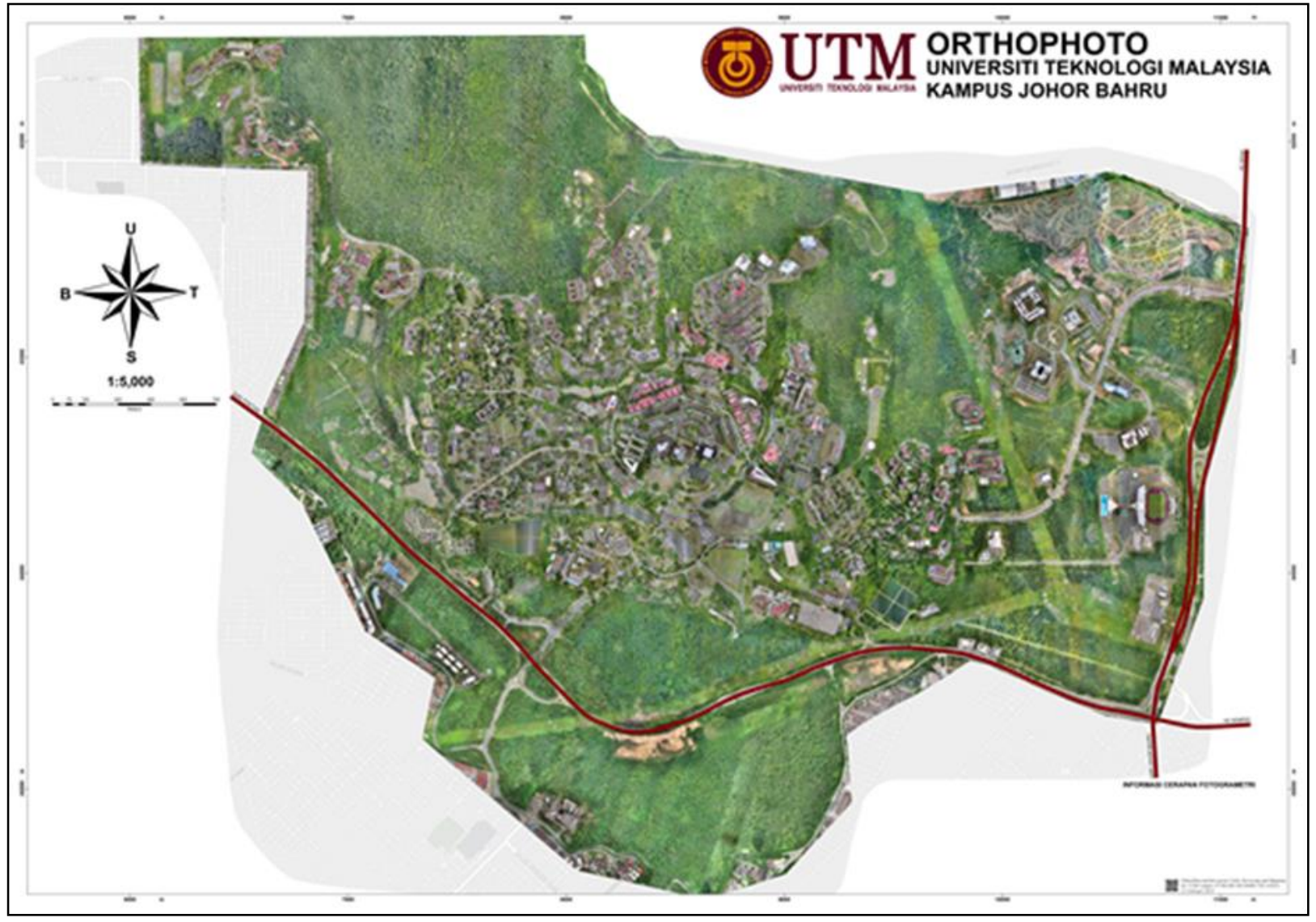



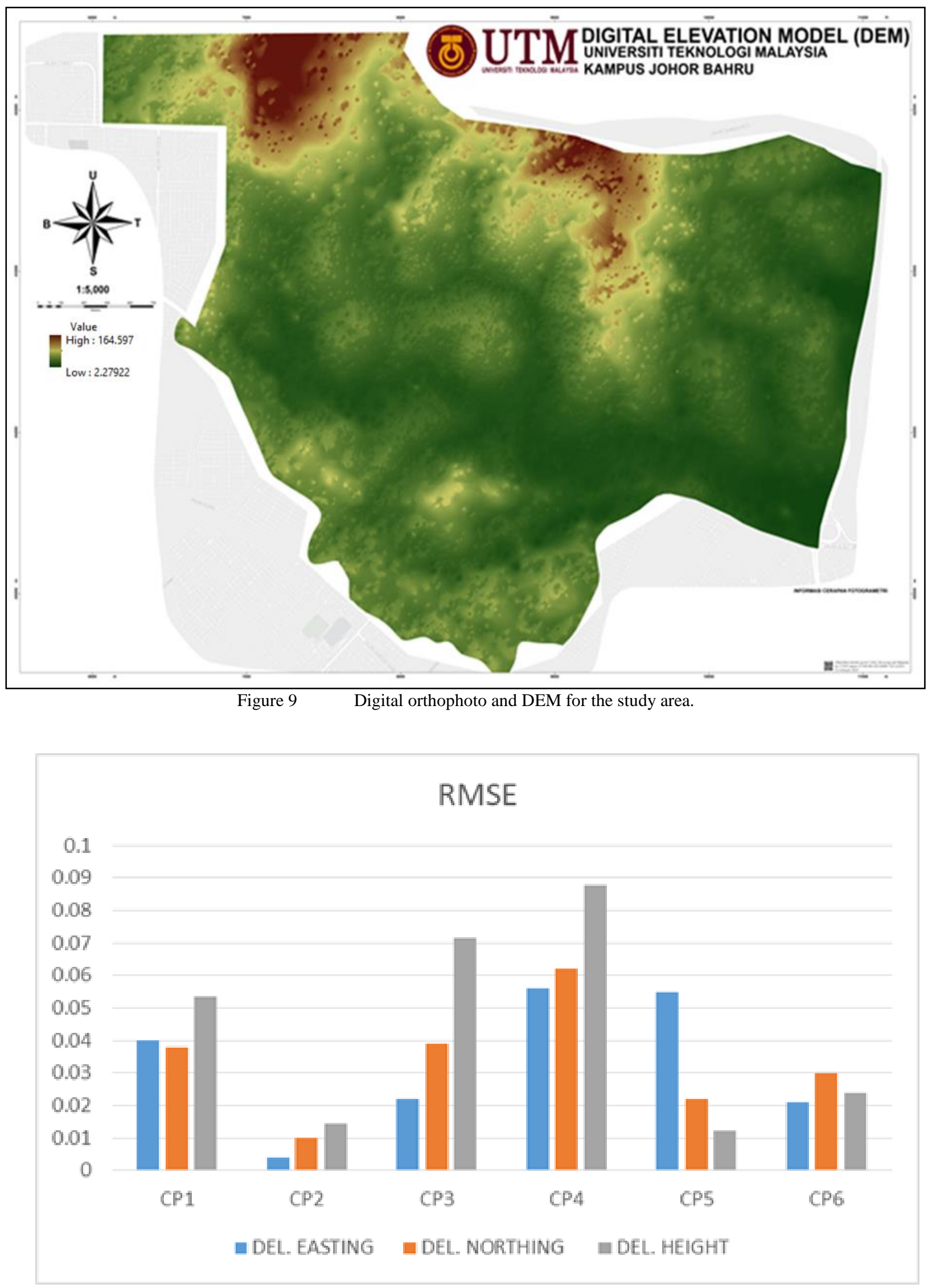

Figure 10 Error for each CP in horizontal and vertical component. 
The International Archives of the Photogrammetry, Remote Sensing and Spatial Information Sciences, Volume XLII-4/W16, 2019 6th International Conference on Geomatics and Geospatial Technology (GGT 2019), 1-3 October 2019, Kuala Lumpur, Malaysia

Table 2: RMSE of horizontal and vertical component.

\begin{tabular}{|c|c|c|c|}
\hline $\begin{array}{l}\text { Check } \\
\text { Point }\end{array}$ & $\begin{array}{l}\text { Del. Easting } \\
\text { (m) }\end{array}$ & $\begin{array}{l}\text { Del. Northing } \\
\text { (m) }\end{array}$ & $\begin{array}{l}\text { Del. Height } \\
\text { (m) }\end{array}$ \\
\hline CP1 & 0.04 & 0.038 & 0.053 \\
\hline CP2 & 0.004 & 0.01 & 0.014 \\
\hline CP3 & 0.022 & 0.039 & 0.071 \\
\hline CP4 & 0.056 & 0.062 & 0.088 \\
\hline CP5 & 0.055 & 0.022 & 0.012 \\
\hline CP6 & 0.021 & 0.03 & 0.024 \\
\hline RMSE & \multicolumn{2}{|c|}{0.048} & 0.044 \\
\hline
\end{tabular}

\subsection{Accuracy Assessment}

Accuracy analysis was performed by using the CPs established in the study area and identical points as extracted from the UAV processing result. The calculations were carried out as follow (Azmi et al., 2014; Darwin et al., 2014);

$$
\mathrm{RMSE}=\frac{\sqrt{(A i-B i)^{2}}}{n}
$$

The result from the calculation can be found at Figure 10 and Table 2. According to Table 2, the average RMSE of horizontal and vertical components for UAV final product were $0.048 \mathrm{~m}$ and $0.044 \mathrm{~m}$, respectively.

\subsection{Mapping Subsurface Profile}

Two types of geophysical data were involved in this study which are resistivity and seismic data. The resistivity data processing has been utilized RESIS2DINV software to generate 2D resistivity profile. Meanwhile, the seismic data has been processed by using FIRSTPIX and GREMIX15 software to generate two-dimensional (2D) seismic refraction profile.

Based on the resistivity results, it indicates that the depth is between $310-340 \mathrm{~m}$ with resistivity value of $0-50,000 \mathrm{Ohm}$ (Figure 11-14). Meanwhile, the seismic result indicate that the depth is between $65-70 \mathrm{~m}$ with seismic velocity value in 250 $8,000 \mathrm{~m} / \mathrm{s}$ as shown in Figure 15 . In the study, zone of low resistivity value is $300 \mathrm{Ohm}$, which was detected at resistivity line R2 and R3. This value is interpreted as saturated zone where it shows the potential groundwater resources. The results of seismic were divided into two layers of subsurface material. The first layer from $0 \mathrm{~m}$ to $20 \mathrm{~m}(250-1500 \mathrm{~m} / \mathrm{s})$ which consists of topsoil meanwhile the second layer is between $20 \mathrm{~m}$ to $70 \mathrm{~m}$ $(1500-8000 \mathrm{~m} / \mathrm{s})$ which consists of weathered rock of granite. Both geological map and geophysical parameter profile have been integrated to generate subsurface profile for groundwater potential zone.

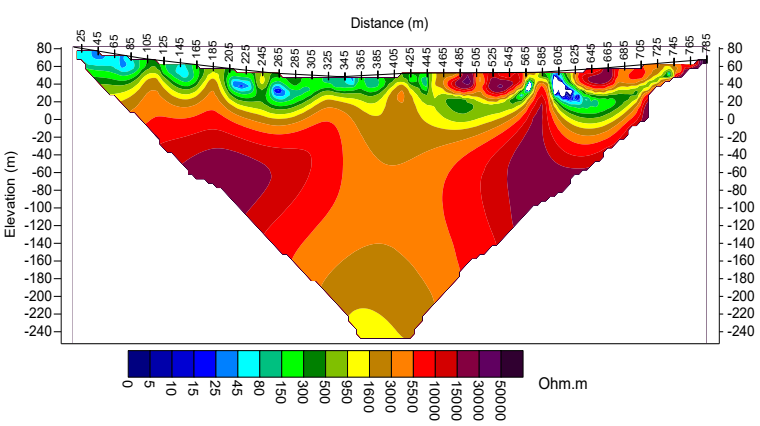

Figure 11. Resistivity section of line R1

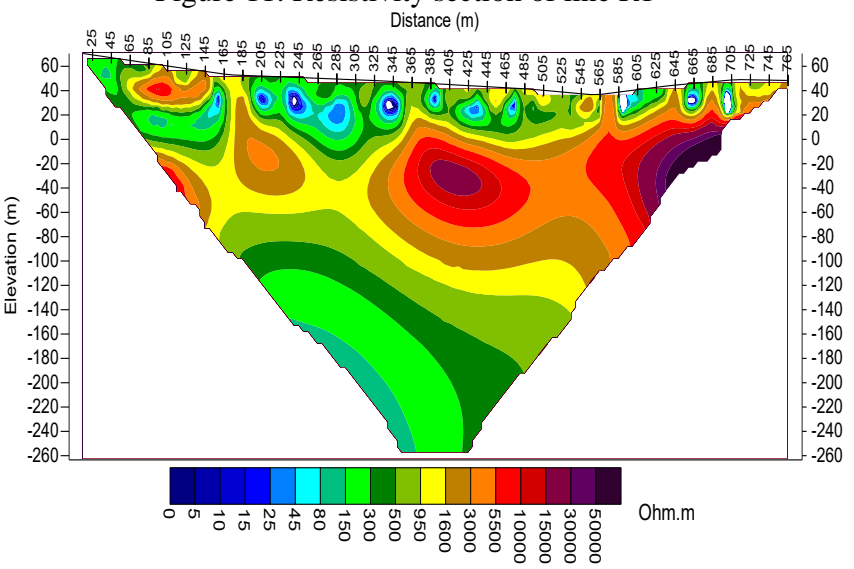

Figure 12. Resistivity section of line R2

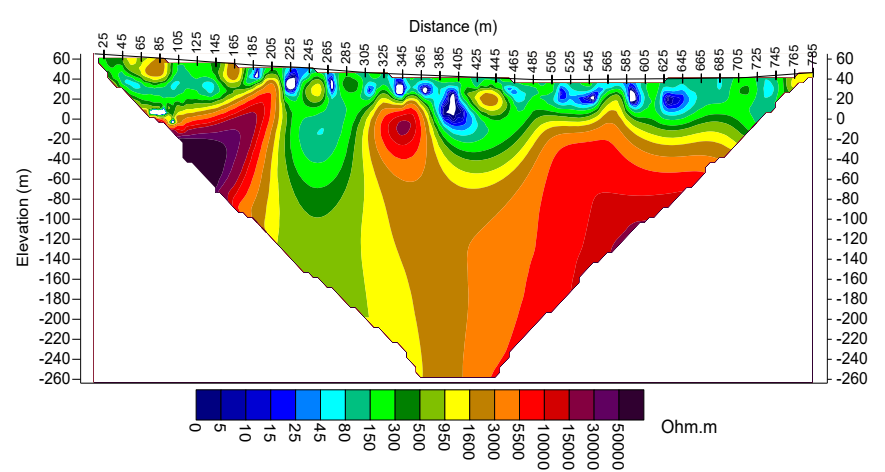

Figure 13. Resistivity section of line R3 


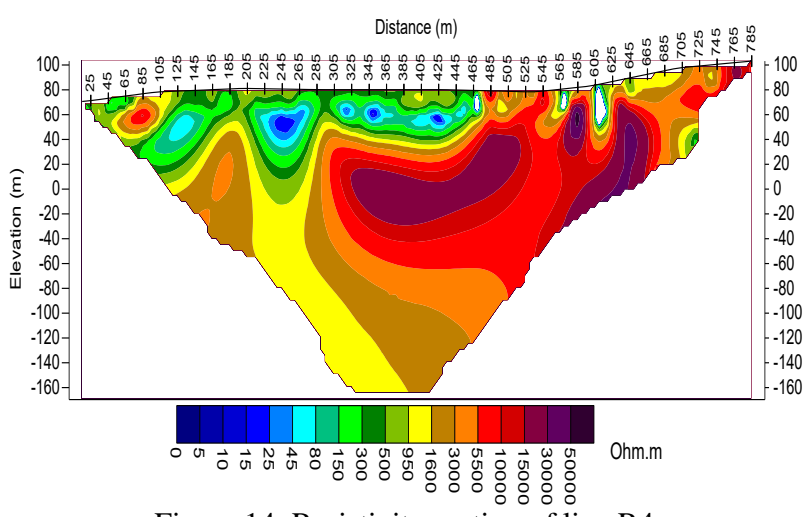

Figure 14. Resistivity section of line R4

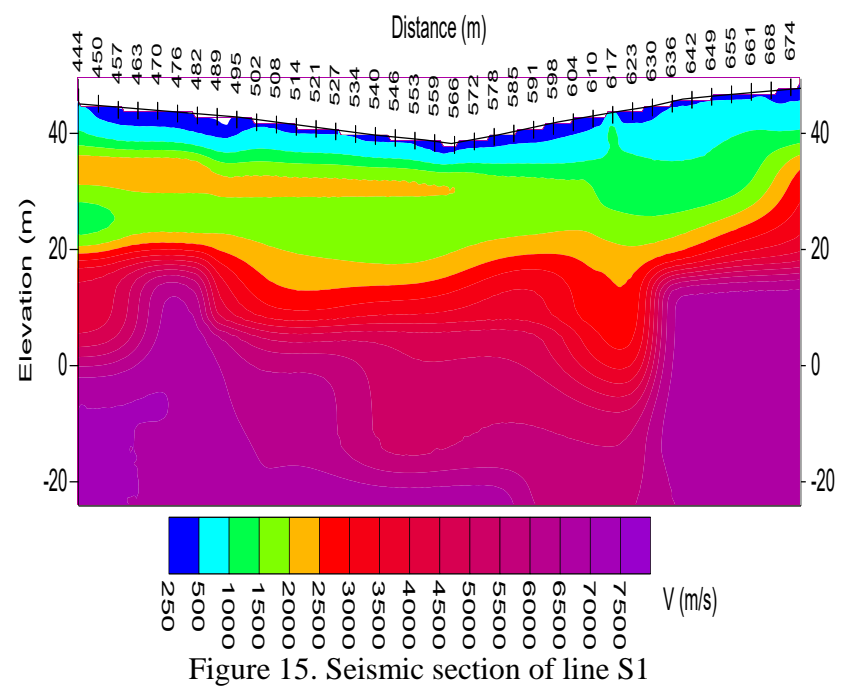

\section{CONCLUSION}

The aim of this research project is to support groundwater exploration by employing the geospatial approach. The potential area of groundwater exploration has been focused at UTM campus Johor Bahru in south of Johor where major water shortage frequently happened. The primary data which consist of GPS measurements and UAV digital aerial image were utilised in this study to produce the topographic map of the study area. It was found that the average RMSE for horizontal and vertical components of the topographic map were less than $5 \mathrm{~cm}$. Meanwhile, the secondary data consist of the existing geologic map has been digitized and georeferenced by using GIS and GPS techniques.

There are two types of geophysical method data collections had involved, which were resistivity and seismic data. Based on the resistivity results, it indicates that zones of low resistivity value is $<300 \mathrm{Ohm}$ which were detected at resistivity lines R2 and $\mathrm{R} 3$, and interpreted as saturated zone with potential groundwater resources. All the datasets had been integrated into a geospatial database which is useful to provide insight in decision making and future planning for groundwater exploration in the study area.

\section{ACKNOWLEDGEMENT}

The authors would like to acknowledge the Universiti Teknologi Malaysia for the research funding under UTM RMC vot number Q.130000.7627.12H33 and RJ.130000.7627.4J34. In addition, the authors would also like to thank Centre of Tropical Geoengineering (GEOTROPIK) and Geomatic Innovation Research Group (GnG) for sharing knowledge, expertise and data throughout the implementation of this project.

\section{REFERENCES}

Abou-Elela, S. I., Hellal, M. S., Aly, O. H., \& Abo-Elenin, S. A. (2019). Decentralized wastewater treatment using passively aerated biological filter. Environmental technology, 40(2), 250260 .

Adiat KAN, Nawawi MNM, Abdullah K (2012) Assessing the accuracy of GIS-based elementary multi criteria decision analysis as a spatial prediction tool-A case of predicting potential zones of sustainable ground water resources.

Ahmed, F., Siwar, C., \& Begum, R. A. (2014). Water resources in Malaysia: Issues and challenges. Journal of Food, Agriculture \& Environment, 12(2), 1100-1104.

Azmi, S. M., Ahmad, B., \& Ahmad, A. (2014). Accuracy assessment of topographic mapping using UAV image integrated with satellite images. In IOP Conference Series: Earth and Environmental Science (Vol. 18, No. 1, p. 012015). IOP Publishing.

Darwin, N., Ahmad, A., \& WAAWM, A. (2014). The potential of low altitude aerial data for large scale mapping. Jurnal Teknologi, 70(5).

Hatta A. K. (2010). Issues and Challenges of Groundwater Data Collection, Organisation and Usage.

Jhariya, D. C., Kumar, T., Gobinath, M., Diwan, P., \& Kishore, N. (2016). Assessment of groundwater potential zone using remote sensing, GIS and multi criteria decision analysis techniques. Journal of the Geological Society of India, 88(4), 481-492.

Kumar, P., Herath, S., Avtar, R., \& Takeuchi, K. (2016). Mapping of groundwater potential zones in Killinochi area, Sri Lanka, using GIS and remote sensing techniques. Sustainable Water Resources Management, 2(4), 419-430.

Manap, M. A., Sulaiman, W. N. A., Ramli, M. F., Pradhan, B., \& Surip, N. (2013). A knowledge-driven GIS modeling technique for groundwater potential mapping at the Upper Langat Basin, Malaysia. Arabian Journal of Geosciences, 6(5), 1621-1637.

Mishra, A. K., Upadhyay, A., Srivastava, A., \& Rai, S. C. (2019). Probabilistic groundwater recharge zonation in hard rock terrain using geospatial techniques in Veniar watershed, South India. Ecohydrology \& Hydrobiology

Mohamad Faizal Tajul Baharuddin (2016). Remapping of water resources in Johor opens up opportunities for alternatives. 
https://www.nst.com.my/news/2016/05/142888/remappingwater-resources-johor-opens-opportunities-alternatives.

Moss R, Moss GE (1990) Handbook of ground water development.Wiley-Interscience, New York, pp 34-51.

Mukherjee P, Singh CK, Mukherjee S (2012) Delineation of groundwater potential zones in arid region of India-a remote sensing and GIS approach. Water Resour Manag 26(9):26432672.

Nag, S. K., \& Chowdhury, P. (2019). Decipherment of potential zones for groundwater occurrence: a study in Khatra Block, Bankura District, West Bengal, using geospatial techniques. Environmental earth sciences, 78(2), 49

Nair, N. C., Srinivas, Y., Magesh, N. S., \& Kaliraj, S. (2019). Assessment of groundwater potential zones in Chittar basin, Southern India using GIS based AHP technique. Remote Sensing Applications: Society and Environment, 100248.

Nescerecka, A., Juhna, T., \& Hammes, F. (2018). Identifying the underlying causes of biological instability in a full-scale drinking water supply system. Water research, 135, 11-21.

Pandey, N. K., Shukla, A. K., Shukla, S., \& Pandey, M. (2014). Assessment of underground water potential zones using modern geomatics technologies in Jhansi district, Uttar Pradesh, India. The International Archives of Photogrammetry, Remote Sensing and Spatial Information Sciences, 40(8), 377.

Paterson, R. R. M., Kumar, L., Taylor, S., \& Lima, N. (2015). Future climate effects on suitability for growth of oil palms in Malaysia and Indonesia. Scientific reports, 5, 14457.

Rahman, A. (2008). A GIS based DRASTIC model for assessing groundwater vulnerability in shallow aquifer in Aligarh, India. Applied geography, 28(1), 32-53.

Rolia, E., \& Sutjiningsih, D. (2018, June). Application of geoelectric method for groundwater exploration from surface (A literature study). In AIP Conference Proceedings (Vol. 1977, No. 1, p. 020018). AIP Publishing.

Saad, R., Nawawi, M. N. M., \& Mohamad, E. T. (2012). Groundwater detection in alluvium using 2-D electrical resistivity tomography (ERT). Electronic Journal of Geotechnical Engineering, 17, 369-376.

Sajjad, H., Iqbal, M., \& Bhat, F. A. (2014). Integrating geospatial and geophysical information for deciphering groundwater potential zones in Dudhganga catchment, Kashmir Valley, India. American Journal of Water Resources, 2(1), 1824.

Savita, R. S., Mittal, H. K., Satishkumar, U., Singh, P. K., Yadav, K. K., Jain, H. K., \& Davande, S. (2018). Delineation of Groundwater Potential Zones using Remote Sensing and GIS Techniques in Kanakanala Reservoir Subwatershed, Karnataka, India. Int. J. Curr. Microbiol. App. Sci, 7(1), 273-288.

Tan, S. T., Lee, C. T., Hashim, H., Ho, W. S., \& Lim, J. S. (2014). Optimal process network for municipal solid waste management in Iskandar Malaysia. Journal of Cleaner Production, 71, 48-58.
Thakur, D., Bartarya, S. K., \& Nainwal, H. C. (2018). Mapping groundwater prospect zones in an intermontane basin of the Outer Himalaya in India using GIS and remote sensing techniques. Environmental earth sciences, 77(10), 368

Yang, F., Gao, P., Li, D., Ma, H., \& Cheng, G. (2018, January). Application of comprehensive geophysical prospecting method in groundwater exploration. In IOP Conference Series: Earth and Environmental Science (Vol. 108, No. 3, p. 032022). IOP Publishing.

Revised August 2019 